\title{
Marguerite Bottard (1822-1906), Nurse under Jean-Martin Charcot, Portrayed by G. Gilles de la Tourette
}

\author{
Olivier Walusinski
}

Brou, France

\section{Key Words}

G. Gilles de la Tourette - Jean-Martin Charcot •

Marguerite Bottard

\begin{abstract}
Hospitals in Paris underwent considerable change at the end of the 19th century. As they moved from providing accommodation to care, their mission shifted from helping to healing. The glorification of scientific progress, as opposed to religious obscurantism, affected all of French 'Republican' society, in particular a significant part of the medical profession, led by figures such as D.M. Bourneville, former interne (house officer) under J.M. Charcot and also his publisher. Bourneville helped bring about the creation of nursing schools and the gradual replacement of religious orders by educated secular nurses. Marguerite Bottard, Charcot's chief nurse made famous by A. Brouillet's painting 'Une leçon clinique à La Salpêtrière', would be glorified and decorated as a model for this movement. A letter by G. Gilles de la Tourette to Charcot's successor F. Raymond, never before published, illustrates this progressive current of thought and revisits the struggle to secularise hospitals under the Third Republic in France. At the same time, it renews interest in the exemplary career of a nurse whose name was recently given to a building at La Salpêtrière Hospital.
\end{abstract}

Copyright $\odot 2011$ S. Karger AG, Base

\section{KARGER}

Fax +4161306 1234 E-Mail karger@karger.ch www.karger.com
(C) 2011 S. Karger AG, Basel

0014-3022/11/0655-0279\$38.00/0

Accessible online at:

www.karger.com/ene
At a time when impressionist painting was emerging and flourishing, André Brouillet (1857-1914), a student of Jean-Léon Gérôme (1824-1904), remained a very academic painter of countrysides and historical events during the French Third Republic (the Czar, Czarina and French President at a meeting of the Académie Française on 7 October 1896; Jules Ferry approving the drawings for the new Sorbonne University; Emile Roux administering the croup vaccine at the Hôpital Trousseau in 1895). He has remained well known for a painting he presented at the 'Salon des Indépendants' in 1887, entitled 'Une leçon clinique à La Salpêtrière' (A clinical lesson at La Salpêtrière) $[1,2]$. The central figure is Jean-Martin Charcot (1825-1893), who occupied the first Chair of Neurology created for him in 1882. Charcot is conducting one of his famous 'Friday lessons'. We see him examining the hysterical patient 'Blanche' Marie Wittmann, who is being supported by Joseph Babinski (1857-1932). The audience is composed of Charcot 'coterie of students, friends and admirers, who filled the back and sides of the classroom' as Pierre Marie reported (1853-1940) [3]. Except for the patient, this painting only shows two female faces. In the background, to the far right, stands a young nurse, Mrs. Ecary, but the older woman in front of her, holding out her arms as if to support the fainting patient, is Marguerite Bottard (1822-1906), Charcot's chief nurse or surveillante (fig. 1). 
Fig. 1. Anonymous. Art exhibition, Salon de 1887. Illustrated catalogue, painting and sculpture. Librairie d'art Ludovic Baschet, Paris 1887 (author's private collection).

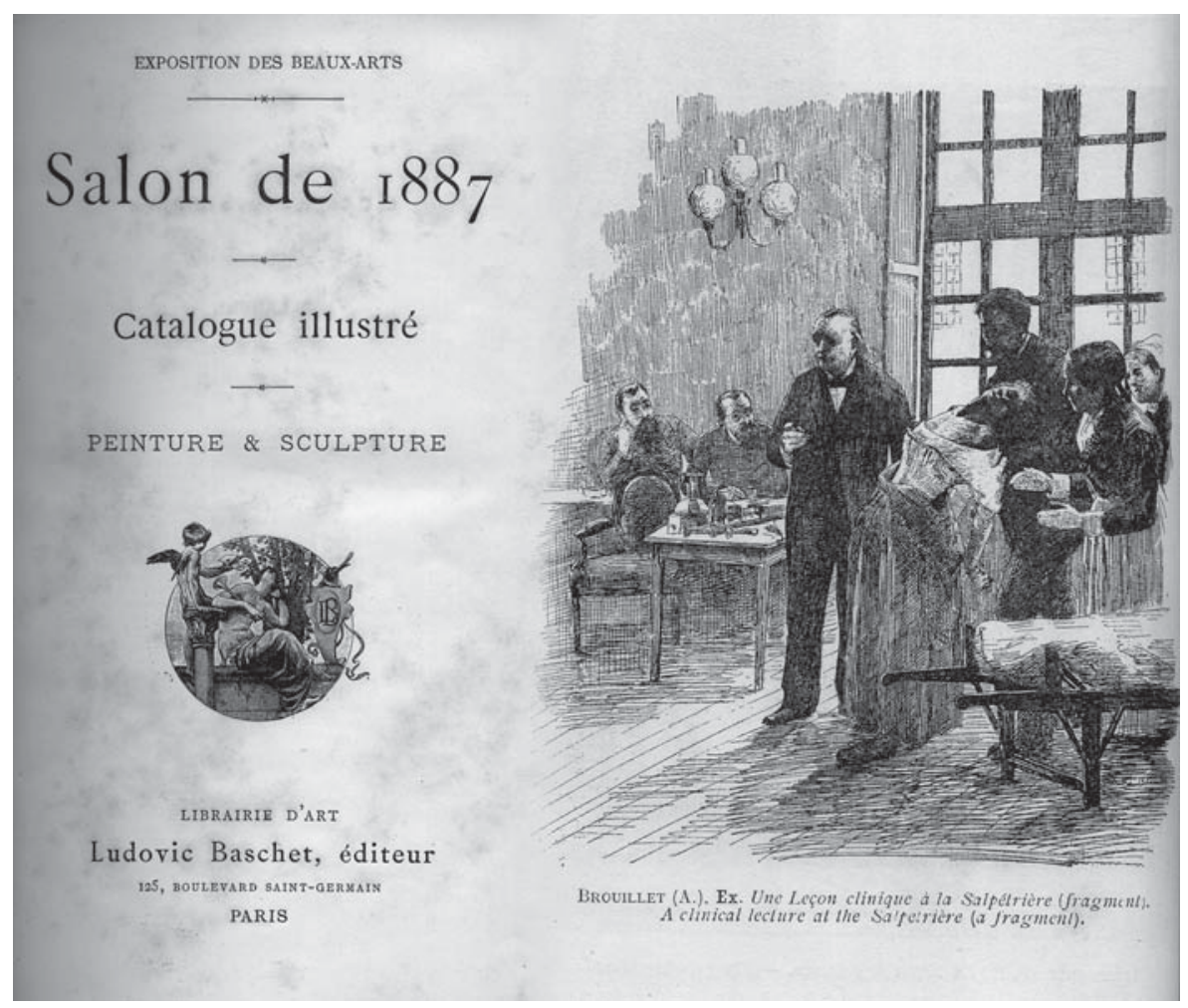

As we discuss below, this devoted woman would become, unbeknownst to her, a heroine of the French republican ideal and a model of the secularisation of hospital personnel at the end of the 19th century in France [4].

Marguerite Bottard was born on 29 January 1822 in Charny in Bourgogne (fig. 2). She was the fourth of 15 children in a family of poor peasants. At a very young age she learned to care for her younger siblings, while they were working in the fields. In 1840, at age 18, she went to Paris to be with one of her sisters, who was working as a maid for the La Salpêtrière Hospital économe (supplies manager/bookkeeper). On the recommendation of the économe, Bottard was hired at La Salpêtrière on 12 January 1841 as a fille de salle (cleaning duties, assisted with simple care-giving). The nursing profession did not yet exist at the time; care was provided by the religious orders [5, 6]. On 20 March 1841, due to a lack of personnel, Bottard became a substitute soignante (care-giver). Eleven years later in January 1852, at the age of 30 , she was assigned to the department that cared for 'alienated' or psychiatric patients. She became sous-surveillante (assistant chief nurse) in September 1852, after a terrible cholera epidemic in 1849. She successively worked under two students of Jean-Etienne Esquirol (1772-1840), first Jean-

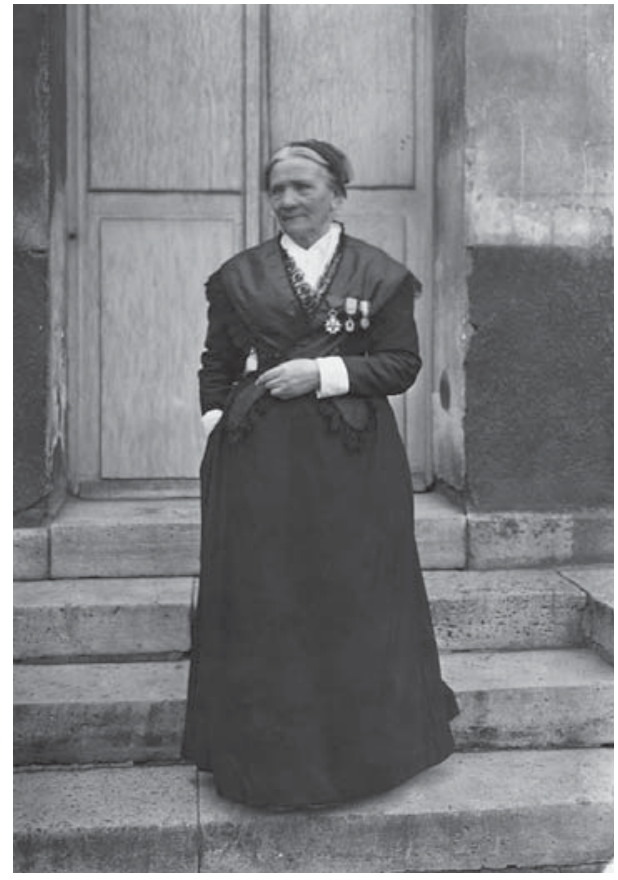

Fig. 2. Photo of Marguerite Bottard. Archives AP-HP, Paris, France (with permission). 
Pierre Falret (1794-1870) for 9 years, followed by Ulysse Trélat (1795-1879). She then worked under Louis Delasiauve (1804-1893) and Henri Legrand du Saulle (18301886). She became surveillante on 1 October 1861 in the 'Petites Loges' department for hysterics and epileptics, the position she held when Charcot incorporated this service into his division in 1870, during a smallpox epidemic in Paris. She worked for Charcot until his death in 1893 , then for Edouard Brissaud (1852-1909), interim successor to the Chair of Neurology, and finally for Fulgence Raymond (1844-1910). Bottard retired on 1 August 1901 at the age of 79 after 60 years of service. She moved into the Pavillon des Reposantes, a house on the grounds of the hospital where employees who had worked for more than 20 years were given room and board, a privilege dating from Cardinal Jules Mazarin (1602-1661). She died at age 84, on 14 November 1906 [7, 8].

Bottard led a life of abnegation and self-imposed reclusion; legend has it that during a period of 3 years she never once left La Salpêtrière and asked for no holidays. Honoured in 1889 by the Ordre des Palmes Académiques, Bottard's exemplary career helped advance the secularisation of hospital nursing staff, a cause defended by Désiré-Magloire Bourneville (1840-1909), founder of the first nursing school [9]. Known for his Republican convictions, Bourneville met Bottard when he was an interne (house officer) under Charcot, who shared his ideas. This is revealed in a posthumous homage to Charcot in the newspaper L'Univers dated 18 August 1893: 'a worker and a scholar, whose studies would have benefitted from taking an antireligious turn less often' $[10,11]$. Charcot's biographer Georges Guillain (1876-1961) highlighted that Charcot was a friend of Léon Gambetta (1838-1882), a politician who emphasised social and economic reforms and opposition to the regime of the Second Empire, a republican leader who later became the President of the Council of Ministers [12]. Bourneville's major journalistic work was the foundation and the editorship of $L e$ Progrès Médical, a militant republican journal that promoted medicine as a science, institutional reform and was seen as the voice of Charcot and the medical avantgarde [13].

On 12 January 1891, Charcot paid a hagiographic tribute to his surveillante at the ceremony for the 50th anniversary of her arrival at La Salpêtrière, attended by representatives of the administration, guests and Charcot's family. In the fight to secularise hospitals, the glory of Marguerite Bottard may seem like the instrumentalisation of a quiet career entirely devoted to the relief of immense suffering. As Bottard was in charge of 400 patients simultaneously, Charcot was able to say of her: 'As a simple layperson, having no other stimulant than the imperious sense of professional dignity and determination which is indeed sharpened in you by a profound sympathy for the disinherited, the incurable, the physically and morally deformed, in short for the unfortunate of all sorts - have you not for more than 50 years, quietly, modestly, with no other aim than the satisfaction of your conscience, with no other support than your ardent heart, for the sake of goodness, have you not led this life of abnegation and sacrifice demanded by your honourable position? For thirty years, perhaps a little more, you and I have walked side by side here each day, in this great asylum of human misery known as La Salpêtrière, treating and comforting patients as best we can, each according to our special functions. There are some who claim that secular surveillantes in our hospitals are incapable of exercising their functions with this absolute selflessness, this unlimited devotion, these moral qualities they claim are unique to surveillantes of the other system. Having known you, I will not hesitate to say it, I even insist on declaring loud and clear, on proclaiming publicly that those who hold this view are fooling themselves or fooling everyone else [...]. Yes, on behalf of the physicians of this hospital, whom you have so intelligently, so generously seconded in the accomplishment of their task, on behalf of the innumerable patients whose pain you have relieved, whom you have loved, uplifted even and how many times (who can say?), without any other motivation than your love of humanity; patients you have brought back to the straight and narrow ... I thank you on behalf of all these people' [14].

These words should be compared with those of physician Carl Potain (1825-1901), student of Jean-Baptiste Bouillaud (1796-1881) and teacher of Henri Vaquez (1860-1936), and notably with those of surgeon Armand Després (1834-1896) as reported by Bourneville, his colleague on the Conseil Municipal de Paris. Bourneville wrote in Le Progrès Médical on 5 March 1881: 'For Mr. Després, the secular nurse, a wife and mother, will always choose her household over her patients [...]. At La Salpêtrière, whether married or not, surveillantes are at their stations whenever they should be, and if one of them were to leave her duties and return home, the director would swiftly correct this issue [...]. As for nuns, although they have no households, do they not have other, equally distracting preoccupations, because of the rules of their communities? Mass, the rosary, salvation, the chapter, penance, the month of Mary, the month of Saint-Joseph, the stations of the cross, Advent, Lent, etc., etc. [...] we 


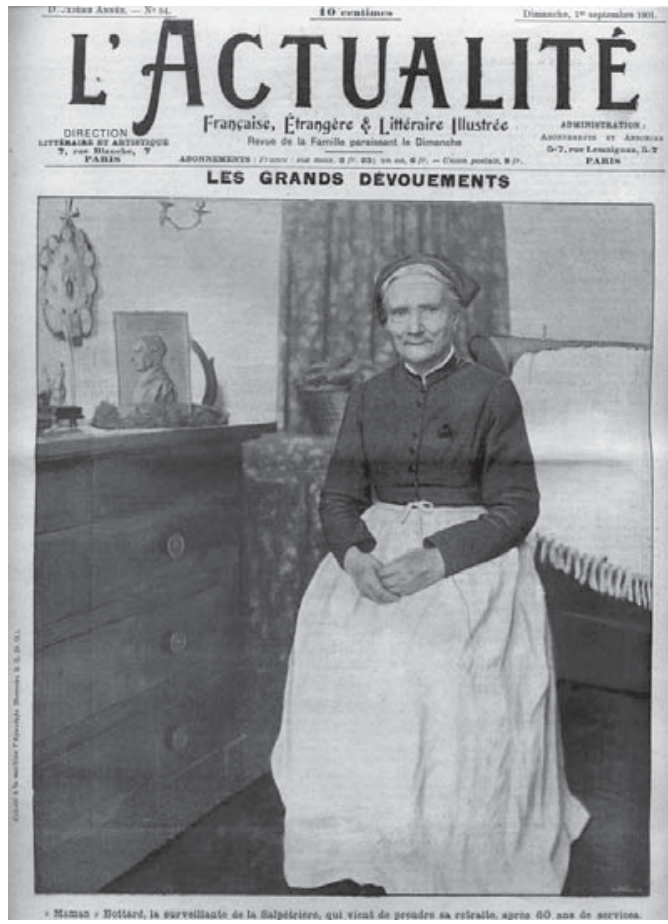

Fig. 3. L'Actualité, 1 September 1901 (10th year, No. 84) (author's private collection).

maintain that by allowing its surveillantes the time to take care of their households, the Assistance can ask more hours from them than it can from nuns [...]. One can scarcely accept the notion that sisters will always win out over secular nurses, "as zealous and knowledgeable as they are in other domains". What then are the requisite qualities set forth by Mr. Potain? The greatest zeal, the greatest knowledge does not satisfy him. Alas, what he requires is ignorance; for him, the knowledge imparted on surveillantes makes them inferior. They are disagreeable pedants, pretentious fools, affecting an understanding of medicine' [15-17].

In this context, it is easy understand how Marguerite Bottard became the prototype secular nurse shaped by the Republic and by the most progressive contingent of the medical profession, represented by Charcot and his students Bourneville and Georges Gilles de la Tourette (19571904) $[18,19]$. The latter, interne then chef de clinique (specialist registrar) under Charcot, was very fond of Bottard, whom he called 'Mum Bottard'. His personal archives contain moving accounts of how he joined forces with his friend Octave Lebesgue, a journalist at L'Eclair then at Le Temps (1857-1933, pen name Georges Montorgueil) to ensure Bottard was publicly honoured. On two occasions, he met with Louis Barthou (1862-1934), French Minister of the Interior at the time. In two letters from December 1897 to his journalist friend, Gilles de la Tourette reports 'having spoken of Mademoiselle Bottard during a meeting the Minister, who was very kind'. It is likely he went to support Bottard's candidature for the rank of chevalier in the Légion d'Honneur, a rare distinction for a woman at that time. Gilles de la Tourette praised Bottard highly in an article in Le Progrès Médical entitled 'Distinguished nurses: Mademoiselle Bottard'. The article summed up her service record, her selflessness and her devotion to her work [20, 21]. As for Montorgueil, he published a mainstream article in the 5 January 1898 issue of L'Eclair, in which he took up the secularisation cause.

Bottard was awarded the Légion d'Honneur on 16 January 1898 (fig. 3). In La Revue Hebdomadaire (weekly paper specialising in fiction), Gilles de la Tourette published the following on 22 January 1898: 'When I took a bouquet of violets to Mlle Bottard, chevalier of the Légion d'Honneur, to congratulate her on 2 January, she said to me: "I am very happy. I have only one regret, that Mr. Charcot is not there ... You have all been so good to me". I have known Mlle Bottard for nearly 15 years. Having worked in various positions in the hospital department where she is surveillante, I was able to observe her eminent character; she wears her modest head scarf as proudly as the Légion d'Honneur medal. Mlle Bottard is seventy-six years old according to her birth certificate, but she is still young and affable under the small black bonnet that covers her white locks. Everything in her exudes compassionate goodness, a virtue she has practised widely for the fifty-seven years she has lived amongst suffering patients [...]. The founding of the Clinic for Nervous System Disorders increased her duties and responsibilities. Charcot's growing renown drew hundreds of patients, and students flocked from everywhere, jostling for the chance to hear the master speak. Mlle Bottard watched over everything, such as the care given the patients and the arrangements for Charcot's teaching. She was the first to rise in the morning and the last to retire at night. Managing such a department was not always easy; Mlle Bottard knew how to smooth away problems. Her beneficial influence was felt everywhere, even during the petty rivalries that sometimes sprang up between the students. At these times she would enter Mr. Charcot's office and clear the clouds with a few words, dissolving the threatening storm. She did all of this quietly and simply, with the dignity that characterises her, based on her respect for herself and for other people, based on her deep abnegation and her inalterable and serene goodness' [14]. 


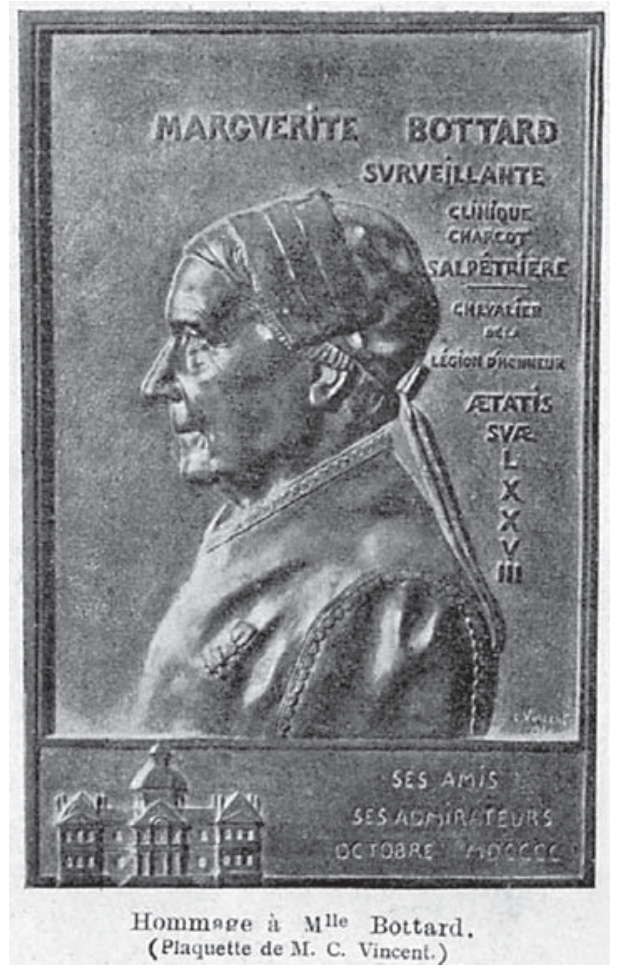

Fig. 4. La Vie Illustrée, No. 108, 9 November 1900. 'Hommage à Mlle Bottard (Plaquette de M.C. Vincent)'. Paris, Juven, 1898-1912 (author's private collection).

On 27 October 1900, Gilles de la Tourette once again took up his pen to write to Fulgence Raymond ('You may find this material useful') to help him prepare the speech written to commemorate Marguerite Bottard's retirement [22]. Gilles de la Tourette notes that on this occasion, Bottard would be given a sculpture by G. Vincent 'as a gift from himself and 5 or 6 friends' (fig. 4).

Paris, 27 October 1900

My Dear Teacher,

I am sending you a few details on Mademoiselle Bottard. As you will of course be giving her the sculpture, if you want to say a few words to her, here is some information you may find useful.

Mlle B., 78 years old, began working at La Salpêtrière as a nurse around 60 years ago. She came straight out of her little village in Bourgogne with a willing heart, but she was the fourth of 15 brothers and sisters and during the bad years, her parents had sold everything on the little farm they ran.

On 12 January 1840, after 3 weeks of training, she became a nurse and rapidly began working as a substitute. Ten years later, she had risen to the position of sous-surveillante and for nine years directed the lunatic department run by Falret the elder. In
September 1861, she became surveillante at 'Petites Loges', the department run by Trélat the elder, which Charcot took over 14 years later. For 39 years, she did not leave the little glass box where she dominated and monitored a department of more than 400 people, all of whom she knew by name.

She never asked for a day of leave. Although she journeyed to Dijon, Blois, Saint Dizier, Ariège and even London, it was to accompany the unfortunate lunatics that the city of Paris no longer wanted to keep. This was the case when war was declared in 1870 . She left with 200 patients, considered useless mouths to feed. No one was concerned with helping them escape from Paris, but she led them amongst the solders and trucks, having to sleep under the stars and struggling at every outpost to obtain bread.

She survived several terrible epidemics: smallpox and three outbreaks of cholera, notably the 1849 epidemic which killed hundreds of old patients, not to mention the Director of La Salpêtrière along with internes, surveillantes, administrative personnel, etc.

In 1889, I nominated her for the Ordre des Palmes Académiques.

In 1891, she received the gold medal from the Assistance Publique for her 50 years of service.

In 1893, she was awarded the bronze medal from the Minister of the Interior, rather than the Croix de la Légion d'Honneur for which she had been nominated.

Finally in 1898, on my recommendation, you helped her to obtain the Croix de la Légion d'Honneur, of which she was very deserving.

She has remained humble. While she acknowledges she would have liked to go out with the others to dance, she could not afford a dress 'paid for with her own money' on 10 francs a month, which was her salary for 11 years. Then she earned 17 francs 50. Only after 20 years of service did she begin to earn 35 francs. Over the last few years, she has become rich with her 70 francs a month.

Her sisters had several children, and she took one of her nephews into her care. She would have perhaps married but the man she chose and whom she remembers fondly fell victim to cholera in 1849 .

Always cheerful, always calm, she directed with as much firmness as benevolence the Clinic Charcot, where the Chair of Nervous System Disorders was established. She plans to retire soon, in January 1901, after 60 years of uninterrupted service. She will leave her two small, low-ceilinged rooms, the walls of which are hung with portraits of Charcot and his students, grouped around their teacher by year. In the box that contains her medals, she has kept letters of congratulations from the many people, some of them illustrious, who have written, met and loved her. She will take them with her and enjoy her memories in the little pavilion called 'Reposantes' (a pretty word evoking rest) where she will pass peacefully away.

She could not imagine living anywhere other than La Salpêtrière; the world beyond these walls is unknown to her.

Don't you think, my dear Teacher, that this constitutes a pretty 'Vie de Paris' for your heart? I think you've already done it, in part, but not completely.

'Mum Bottard', as we call her, is a secular saint, and St. Vincent de Paul, who set up La Salpêtrière, was right to employ only laywomen. 
Charcot had a great deal of esteem for Mlle Bottard. She was always by his side when the department was not working properly; she was the one who patched up the small quarrels, the rivalries between students. After working as an interne under Charcot in 1884 , when I became his chef de clinique in November 1887, I ran up against major material difficulties which I will explain to you if you are unaware of them. Disheartened by what was happening, I almost gave up the ghost ... I would have lost everything! 'Mum Bottard' did not hesitate. She told Charcot how much respect and affection I had for him, how poorly assisted I was in my work, etc., etc. And my old Teacher finally understood how much I loved him; since then he has not ceased to show me the same affection. His children understood this and have become our best friends.

If you wish to know, my dear Teacher, this is why I love Mum Bottard; why I nominated her for the Ordre des Palmes Académiques by the intermediary of our friend Leroy, the Office Manager for the Minister of Public Instruction and formerly secretary to Jules Ferry; why I asked you to consider her for the red ribbon [Légion d'Honneur] that your generous heart accorded her.

After having been an interne in this department, after having done 2 years as chef de clinique, I became a professor and began substituting for Charcot last year. You know this because you did me the honour of attending my first lesson. I served as Charcot's replacement for 6 months and perform this duty every year during the holidays.

When I joyfully arrive at work in the department, I start by kissing Mum Bottard on both cheeks, a gesture she returns warmly. I am sad to leave and she is sad to see me go. I wanted to always have an image of her good face before me. This is why, along with 4 or 5 friends and students, I ordered a bronze cast of her, which is very beautiful, very skilfully made. I have set aside a nice copy for you. It will remind of you La Salpêtrière. You loved it there and that is where I met you, which was one of the joys of my life.

Monday morning I will present you with the beautiful sculpture by the artist Vincent along with a modest bouquet, and for all of us there will be rejoicing in heaven. I send you all my affection and respect.

(signed) Gilles de la Tourette (fig. 5)

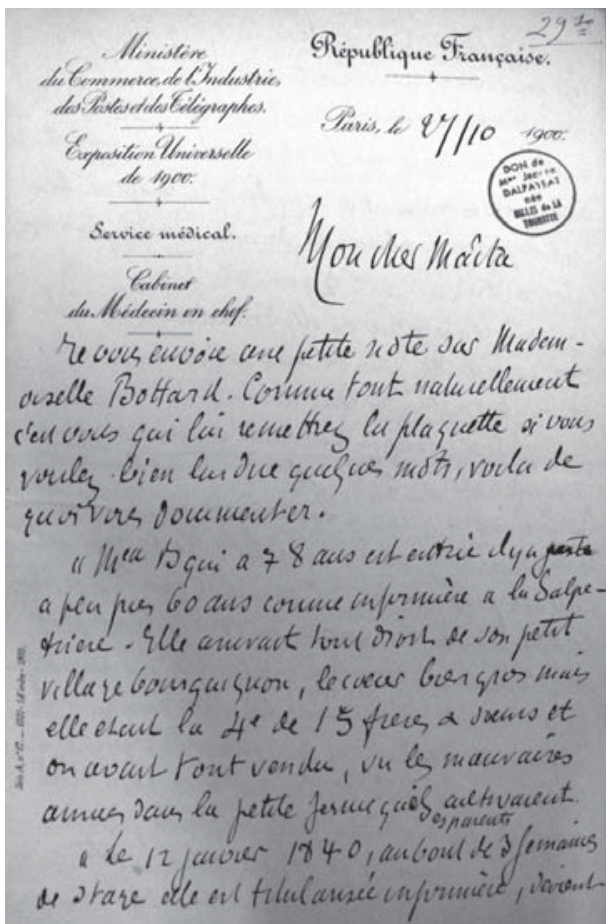

Fig. 5. Letter written by G. Gilles de la Tourette to Prof F. Raymond. Fond Dalpeyrat. Musée Charbonneau Lassay, Loudun, France (with permission).

In addition to speaking of Marguerite Bottard, this text illustrates the megalomaniacal style used by Gilles de la Tourette. It also reveals the first symptoms of the general paralysis that would take his life in 1904. Finally, Gilles de la Tourette wrote this letter on official paper from the 1900 World's Fair in Paris, for which he served as head physician $[23,24]$.

\section{References}

1 Signoret JL: Une leçon clinique à La Salpêtrière (1887) par André Brouillet. Rev Neurol (Paris) 1983;139:687-701.

-2 Telson HW: Une leçon du Docteur Charcot à La Salpêtrière: Lithograph by Eugene Pirodon based on a painting (1887) by André Brouillet. J Hist Med Allied Sci 1980;35:58.

3 Marie P, Eloge de JM: Charcot. Rev Neurol (Paris) 1925;5:731-745.

4 Lalouette J, et al: L'Hôpital entre religions et laïcité: du Moyen Âge à nos jours. Paris, Letouzey \& Ané, 2006, pp 303.
5 Martineaud JP: Les ordres religieux dans les hôpitaux de Paris: les congrégations hospitalières dans les hôpitaux de l'assistance publique à Paris, des fondations à la laïcisation. Paris, l'Harmattan, 2002, pp 430.

6 Boucher L: La Salpêtrière, son histoire de 1656 à 1790, ses origines et son fonctionnement au XVIII ${ }^{\circ}$ siècle. Paris, Aux Bureaux du Progrès Médical, Delahaye \& Lecrosnier, 1883, pp 138.

7 Mesureur A, Raymond F: Mademoiselle Bottard, nécrologie. Prog Méd (Paris) 1906;22: 856-858.

8 Poisson M: Marguerite Bottard (1822-1906). Rev Infirm 2009;150:43-44.
9 Poirier J, Signoret JL: De Bourneville à la sclérose tubéreuse: une époque, un homme, une maladie. Paris, Flammarion MédecineSciences, 1991, pp 206.

10 Paciaroni M, Cittadini E, Bogousslavsky J: Great careers: Cornil, Bouchard, Bourneville and Proust. Front Neurol Neurosci 2011;29:61-70.

11 Lalouette J: Charcot au cœur des problèmes religieux de son temps. Rev Neurol (Paris) 1994;150:511-516.

12 Guillain G: J.-M. Charcot: 1825-1893: sa vie, son œuvre. Paris, Masson, 1955, pp 188. 
-13 Poirier J, Ricou P, Leroux-Hugon V: Birth and death of Charcot's scientific journals. Front Neurol Neurosci 2011;29:187-201.

14 Gilles de la Tourette G: Mademoiselle Bottard. La Revue Hebdomadaire. Paris, PlonNourrit, 1898, vol 7, pp 562-565.

15 Bourneville DM: Sœurs ou Laïques. Prog Méd (Paris) 1881;9:178-181.

16 Bourneville DM: Laïcisation de l'assistance publique: discours prononcés les 3,8 et 9 août 1887 aux distributions des prix des écoles municipales d'infirmières laïques, suivi de Renseignements sur la laïcisation des hôpitaux. Paris, Impr. V. Goupy \& Jourdan, 1887, pp 117-172.
17 Brais B: Désiré Magloire Bourneville and French anticlericalism during the Third Republic; in Porter D, Porter R (eds): Doctors, Politics and Society: Historical Essays. Amsterdam/Atlanta, Rodopi, 1993, pp 311.

18 Leroux-Hugon V: Des saintes laïques: les infirmières à l'aube de la Troisième République. Paris, Sciences en Situation, 1992, pp 225.

19 Leroux-Hugon V: La laïcisation des hôpitaux de Paris et la création des écoles d'infirmières laïques (pp 73-82); in De Bourneville à la sclérose tubéreuse, une homme, une époque, une maladie. Paris, Flammarion, 1991, pp 206.

20 Gilles de la Tourette G: Les infirmières décorées: Mademoiselle Bottard. Prog Méd (Paris) 1898;3:26-45.
21 Walusinski O: Keeping the fire burning: Georges Gilles de la Tourette, Paul Richer, Charles Féré and Alfred Binet. Front Neurol Neurosci 2011;29:71-90.

22 Musée Charbonneau Lassay. Loudun (Vienne). Archives de Georges Gilles de la Tourette. Don Dalpeyrat.

23 Lees AJ: Gilles de la Tourette, the man and his times. Rev Neurol (Paris) 1986;142:808816.

24 Walusinski O, Duncan G: Living his writings: the example of neurologist G. Gilles de la Tourette. Mov Disord 2010;25:2290-2295. 